University for Business and Technology in Kosovo

UBT Knowledge Center

UBT International Conference

2017 UBT International Conference

Oct 28th, 11:00 AM - 12:30 PM

\title{
Unions and Professional Organizations
}

\section{Diamanta Skenderi}

University for Business and Technology, diamanta_skenderi@yahoo.com

Besnik Skenderi

University for Business and Technology, besnik.skenderi@ubt-uni.net

Follow this and additional works at: https://knowledgecenter.ubt-uni.net/conference

Part of the Business Commons

\section{Recommended Citation}

Skenderi, Diamanta and Skenderi, Besnik, "Unions and Professional Organizations" (2017). UBT International Conference. 250.

https://knowledgecenter.ubt-uni.net/conference/2017/all-events/250

This Event is brought to you for free and open access by the Publication and Journals at UBT Knowledge Center. It has been accepted for inclusion in UBT International Conference by an authorized administrator of UBT Knowledge Center. For more information, please contact knowledge.center@ubt-uni.net. 


\title{
Unions and Professional Organizations
}

\author{
Diamanta Skenderi ${ }^{1}$ and Besnik Skenderi ${ }^{2}$ \\ ${ }^{2}$ UBT - Higher Education Institution, Lagjja KALABRIA p.n., Prishtinë, Kosovë \\ 10000 Prishtina, Kosovo \\ diamanta_skenderi@yahoo.com, besnik.skenderi@ubt-uni.net
}

\begin{abstract}
This paper discusses the role of unions, professional organizations and the place business should take in society. In addition, this paper also is about how the company policy should be with regard to the environment, or on dealing with evil regimes. For this paper academic journals have been used and in a last part is provided conclusion.
\end{abstract}

Keywords: unions, professional organizations, social responsibility, employee rights

\section{Role of Unions}

Within last century two social systems had existed in the world, Communism and Capitalism, however, competitive business environment dint exist within countries that has have socialist social system since market was controlled by state. In addition, founder of Communism, Karl Marx, objected to capitalism, as he thought, especially on the ground that it involved alienated labor, while according to Narveson (1988) "One important reply to Marx's criticism has been that he has the wrong target: what spawns these conditions isn't capitalism, it's industrialism" (p. 96). However, within both social system employees had organized themselves in Union organizations with the goal to protect their rights and to have better working conditions (Godard \& Frege, 2013). In addition according to Hagedorn, Paras, Greenwich, \& Hagopian, (2016) "Unions help members gain control over their scheduling and job security, and union membership is associated with increased democratic participation" (p. 989).

However, role of unions should be about enforcing democracy within workplace and it should be used as a voice of all employees regarding wages, health and safety issues and pensions. Furthermore, employees should have the right to join or not to join to unions, however all employees rights should be regulated by law and by constitution, but at current environment when World is facing with risk from terrorism, dictatorial governments and risk of cyber-crime, employee rights and human rights might be seen as utopic request. For those reasons unions should continue to exist and employees should be active participants within labor unions since Godard \& Frege, (2013) concludes that "unions continue to serve a democratization function in workplaces“(p. 164).

\section{Professional Organizations}

As a result of innovations and because of requirement for highly skilled employees, new professions had evolved within couple of last decades (Project Specialist, System Administrator, Programmer, Database Administrator, and Nanotechnology Expert). Professionals are taking advantage compared with other people and according to Narveson (1988) "many (not all) are 
effectively self-employed, making their incomes through fees for their specialized services" ( $p$. 104). In addition, professionals are connected with each other and they are establishing their professional organizations and many professional organizations had created their code of conduct. However, the dilemma could exist with professional's code of conduct since when companies are operating within third world countries or within region that is controlled by authoritarian regime, professional code of conduct will provide guidelines for behavior. For example, Lufthansa had designed airplanes for Nazis in Germany and Dr. Joseph Mandela had conducted genetic researches in concentration camp in Auschwitz, however they had used captured civilians and soldiers and many people had died while they were used as 'resources'. Despite the fact that professional organizations could trigger innovation and exchange professional; knowledge, those organizations and their code of conduct should be substitute for or alternative to normal morality (Narveson, 1988).

\section{Company Policy and Environment}

Companies are operating within legal framework where are also defined requirements regarding environmental protection. In addition, companies have also their internal policies regarding environment that could have more requirements than local legal system where company is operating. According to Kong, Liu, \& Dai (2014), literature review for environment has been divided in to three threads, "the first thread investigates how corporate environmental performances or regulations affect financial performance" (p. 102) while in second category are relationships between corporate environmental protection and capital market and last one is "focusing on investor reactions to the corporate environmental protection effort" (p. 103).

Companies should develop policies regarding their social responsibility about environment protection, despite the fact that sometimes environment policies will oppose business objectives. However, if companies are investing on environment protection their value on stock market will be higher since they will have better reputation. Moreover, Sethi (1979) states that "Business institutions in the United States and other industrially advanced countries have suffered a marked loss in social credibility" (p.63).

\section{Doing Business With Authoritarian Regime}

While conducting business activities at international scale, companies will be dealing with different governments that could represent authoritarian or 'evil' regime. However, at this case two perspectives should be considered, from shareholders perspective the goal of company is to create profit, while sometimes morale dilemma could be raised. From author's experience, during the war in Kosovo in 1999, people had suffered for medicines and for food, while Coke, Cigarettes and Diesel was always present in black market.

According to Narveson (1988) "When we speak of "evil regimes", what we mean is that the government is evil, not that the people in that country are evil" (p.117). In addition, many companies are investing in to pseudo-democracies, such as the Philippines or Turkey (O'Shaughnessy, 2017), and many democratic governments are strategic allies of those states. In addition, corruption as phenomenon is present in every country, however this phenomenon is more expressed within authoritarian regimes and according to Alon, Shaomin, \& Jun (2016) "Corruption affects a society politically, economically, and culturally" (p. 334). Furthermore, world greatest economies where established based on authoritarian regimes, from African Slaves that had worked in cotton fields in USA to prisoners in concentration camps in Germany that had 
built aircrafts and rockets, evil regimes in the name of civilization had used natural and human resources and often this was conducted with blessing from spiritual leaders

\section{Conclusion}

Labor Unions should negotiate with shareholders representatives regarding their wages and working conditions, however they should not have influence on product development since those kind of tentative had failed in the countries where Communism was adopted as social system. As a result of globalization and completion, many companies are entering in markets that are under authoritarian regime and there are cases where companies are outsourcing their operations in pseudo democratic countries. However, in practice what is legal many times is not moral and this matter should be decision that each company should bring based on their vision, mission and based on their values.

\section{References}

1. Alon, I., Shaomin, L., \& Jun, W. (2016). Corruption, regime type, and economic growth. Public Finance \& Management, 16(4), 332-361.

2. Godard, J., \& Frege, C. (2013). Labor unions, alternative forms of representation, and the exercise of authority relations in U.S. workplaces. Ilr Review , 66(1), 142-168.

3. Hagedorn, J., Paras, C. A., Greenwich, H., \& Hagopian, A. (2016). The role of labor unions in creating working conditions that promote public health. American Journal of Public Health, 106(6), 989-995.

4. Kong, D., Liu, S., \& Dai, Y. (2014). Environmental policy, company environment protection, and stock market performance: evidence from China. Corporate Social Responsibility \& Environmental Management, 21(2), 100-112.

5. Narveson, J. (1988). Ethics in the Business and Professional Life.

6. O'Shaughnessy, N. (2017). The politics of consumption and the consumption of politics: how authoritarian regimes shape public opinion by using consumer marketing tools. Journal of Advertising Research, 57(2), 121-126.

7. Sethi, S. P. (1979). A Conceptual Framework for environmental analysis of social issues and evaluation of business response pattern. The Academy of Management Review, 4(1), 63-74. 